\title{
MODERN METHOD USED FOR MEASURING THE INTENSITY OF SOLAR RADIATIONS
}

\author{
GORDAN, I[oan] M[ircea]; GORDAN, C[ornelia] E[milia] \& POP, P[etru] A[drian]
}

\begin{abstract}
Measuring the intensity of solar radiation is one of the directions used at investigation of solar power and necessary for the implementation of photovoltaic systems in a particular geographical area. This can be done by using specific measuring equipment as pyranometer sensors, based on a thermal or photovoltaic principle. In this paper, it is presented a method for measuring solar radiation that has two main components- direct radiation and diffuse radiation, with sensors based on the photovoltaic principle. These data are processed for positioning solar panels, in order their efficiency to be maximized, being critical in the selection of solar panels. The future researches would be foccused on implenetation of solar panels in others areas of Bihor County from Romania.

Keywords: database, solar radiation, solar radiation sensor, virtual imstrument
\end{abstract}

\section{INTRODUCTION}

The environmental concerns about fossil fuels and their constraints along with energy security concerns led to significant interest in using of renewable sources, as wind and solar energy. The renewable energies are almost inexhaustible and provide from the energy of the sun affecting the earth, which include solar, wind, ocean currents, ocean waves, and ocean thermal energy [2, 3].

The global impact of solar energy, under form of solar electricity, solar thermal energy and solar fuels, it has taken better advantage in last years. These demands can serve the need to develop to enhance solar panels, solar photovoltaic efficiencies, decrease system costs and the concentration of solar power, and improve component recyclability [1-3, 9-13, 20-22].

Solar power is consumed from its absorption by some gases in the atmosphere and clouds, and is influenced by some geometric factors, which must be taken into consideration when the surface, where the solar radiation falls, is different from the incident one. The mechanisms, from which the solar radiation intensity is charged at passing through atmosphere, are absorption and scattering. However, the total solar radiation is huge, the area where this radiation can be captured is very large and the energy is diffuse. So, the capture devices must have great areas with solar panels in order to collect the desired solar power. [6, 11, 21].

For the study of solar radiation is significant to share some important parameters such as the solar constant, which is the heat flow per unit received from the sun and solar radiant energy flow. The atmosphere absorbs (retains, filters) X-radiation almost completely and part of the UV (ultraviolet radiation). Water vapor, carbon dioxide and other gases from the atmosphere, contribute to the absorption of solar radiation by the atmosphere. In general, the absorbed radiation can be converted into heat and diffused radiation obtained is returned in all directions in the atmosphere.

From the limit of atmosphere to land surfaces, the solar radiation intensity is reduced because of the above effects have different values, depending on geographical location (latitude, longitude, altitude, etc.), weather conditions and the presence or absence of pollution [21].

Global radiation obtained from the sun, on a horizontal surface at the ground level, in a clear day, is the sum of direct radiation and diffuse radiation. Direct solar radiation depends on the orientation of the receiving surface, atmospheric condition and position in the world, with daily and annual variations depending on the movement of the terrestrial globe. Diffuse solar radiation can be considered the same, regardless of the orientation of the receiving surface, even if, in reality, there are slight differences [11, 20, 21].

In the context of continuous development and growing consumption of energy that reduces pollution, the international scientific community reconsiders all approaches on renewable energies. Among of these, the solar energy has one of the most important potentials all over the world, because for a very long time, the sun has considered a huge source of free energy. As noted previously, the intensity of solar radiation, outside the limits of the atmosphere, was relatively constant and this value has determined experimentally by measurements with specific technology satellites.

The aim of this research is to investigate the measures of solar power radiations in two zones from Romania, to obtain an efficient implementation of solar panels in these areas. For that, we have used an installation with LS 200 solarimeter presented in Fig.1, which it will be presented in details in next.

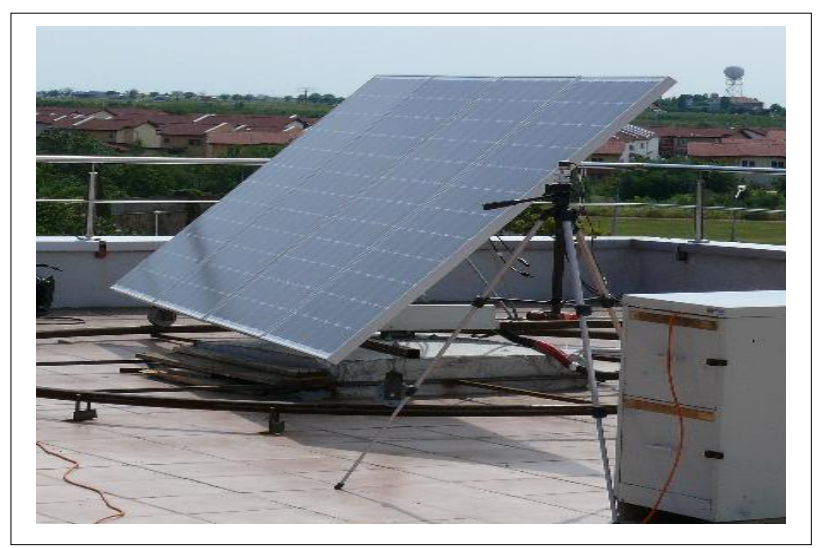

Fig.1. Installation with LS 200 used at measuring of solar power energy 


\section{THEORY}

The term used to define the intensity or flux of solar radiation is irradiance. The solar irradiance at the earth's surface varies greatly depending on factors such as latitude, time of day, time of year, cloud cover, etc. The irradiance can be expressed in $\left[\mathrm{W} / \mathrm{m}^{2}\right]$; if the radiation is separated into its spectrum, the irradiance at a specific wavelength can be expressed as watts per meter squared per nanometer of wavelength.

Max Planck determined that the energy of radiation or photons at a given frequency was simply expressed as constant times the frequency $[2,11]$ :

$$
E=h v=\frac{h c}{\lambda}
$$

where: $E$-is the energy $[\mathrm{J}], v$ - the frequency $[\mathrm{Hz}], c$ - the rate at which radiation travels, or the speed of light $\left[3.0 \times 10^{10} \mathrm{~cm} / \mathrm{s}\right], \lambda$ - the wavelength $[\mathrm{cm}], h$ - Planck's constant $\left[6.63 \times 10^{-34} \mathrm{~J} \cdot \mathrm{sec}\right]$.

The interaction between matter and electromagnetic radiation can result in either the absorption or emission of photons depending on the phenomena being observed.

The clouds have a large effect on irradiance at the earth's surface. Clouds and aerosols scatter radiation while air pollutants such as sulfur dioxide absorb and scatter UV. For UV irradiance, additional factors are ozone and elevation above sea level.

The size of ozone that passed through depends on its concentration in the atmosphere and on the elevation above sea level and the angle of the sun with respect to a point on the surface of earth. So, the higher elevation is above sea level and the shorter path through the atmosphere that the radiation has to travel, due to increasing irradiance. From Fig.2 [2], it can be seen that the lower sun is in the sky and the greater amount of ozone the radiation encounters as it passes to the surface of earth thus lowering irradiance.

The sun's angle depends on the followings factors: the latitude, the time of year, and the time of day.

The angle of sun is defined as the solar zenith angle (SZA), which represents the difference in degrees between directly overhead and suns actual position. So, if the sun were directly overhead, the value of SZA can be zero, which is possible only at latitudes between $23.5^{\circ}$ North and $23.5^{\circ}$ South [2].

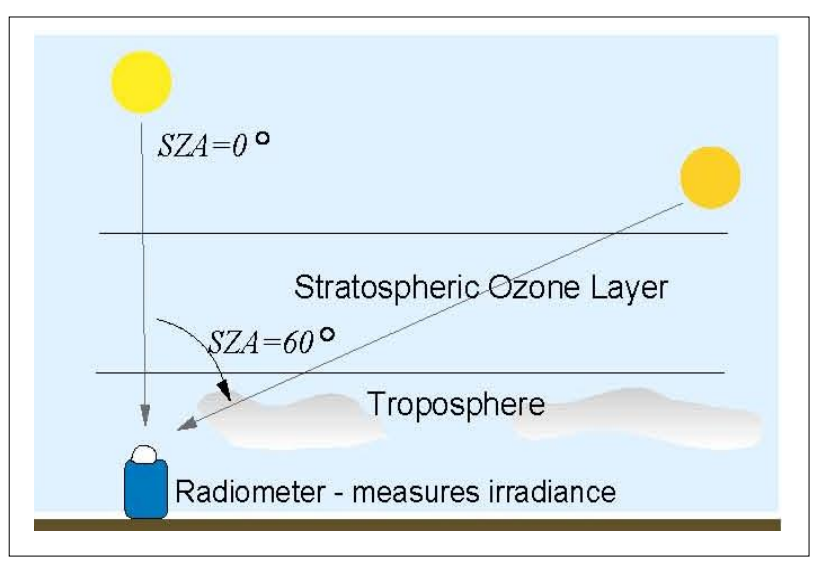

Fig.2. Path length trough atmosphere and solar zenith angle (SZA) [2].
The amount of solar radiations received at a location on the earth's surface depends on the state of the atmosphere and the location's latitude. The intensity of solar radiation reduces with $25-30 \%$ as absorbing on atoms and ions of present gases $\left(\mathrm{O}_{2}, \mathrm{~N}_{2}, \mathrm{CO}_{2}\right.$, Ozone, etc.) at passing through atmosphere. Solar radiation that comes to the earth is known as terrestrial radiation [20].

The values of terrestrial radiation during of a year are between $1370-1393 \mathrm{~W} / \mathrm{m}^{2}$. The formula for calculation of this intensity that falls on the surface at right angle to the direction of the solar radiation is [20]:

$$
I_{o n}=I_{s c} \frac{r}{R^{2}}
$$

where: $r$-is the middle distance of the earth from the sun, $R$ - instantaneous distance of the Earth from the Sun, and $I_{s c}=(1353) \pm 21\left[\mathrm{~W} / \mathrm{m}^{2}\right]-$ solar constant. In a unit time falls at a right on square meter of surface, this energy can be calculated as [20]:

$$
I_{\text {on }}=\left[1+0.0333 \cos \left(\frac{360 n}{365}\right)\right] I_{s c}
$$

where: $n$ is a day in a year that counts from January $1^{\text {st }}$.

The energy of extraterrestrial radiation on horizontal surface has the formula [20]:

$$
I_{o H}=I_{o n} \cos Z
$$

where: $z$ is zenith angle, which can be calculated as:

$$
\cos Z=\sin \alpha=\sin L \sin \delta+\cos L \cdot \cos \delta \cdot \cosh
$$

By substitution of (5) in (4) the energy of extraterrestrial radiation on a horizontal surface for a particular day in a year can be calculated as [20]:

$$
\begin{aligned}
& I_{o n}=\left[1+0.0333 \cos \left(\frac{360 n}{365}\right)\right] I_{s c}(\sin L \sin \delta+\cos L \\
& \cos \delta \cdot \cosh )
\end{aligned}
$$

where: $L$ is local latitude, $\delta$-declination, and $h$-hour angle. The magnitude of hour angle can be calculated as:

$$
h= \pm \frac{1}{4} \text { (number of minutes from local solar time) }{ }^{[0]}
$$

where the + sign applies to afternoon hours and - sign to morning hours. The daily extraterrestrial radiation from the sunrise to the sunset can be calculated as [20]:

$$
\begin{aligned}
& I_{o n}=\frac{24}{\pi} I_{s c}\left[1+0.0333 \cos \left(\frac{360 n}{365}\right)\right](\sin L \sin \delta+\cos L \\
& \cos \delta \cdot \cosh )
\end{aligned}
$$

It's well-known that on the earth's surface come two components of solar radiation; one directly from the sun, named direct solar radiation, and the other originates from dispersing of direct solar radiation in the atmosphere, named diffuse solar radiation). So, the 
global solar radiation is composed by direct and diffuse solar radiation. The direct solar radiation represents a main component of global solar radiation for a clear day. A part of solar radiation that comes indirectly and is scattered or reflected from the atmosphere or cloud cover represents the diffuse solar radiation. So, the entire daily solar radiation than to a horizontal surface is:

$$
I_{T}=I_{B}+I_{d}
$$

where: $I_{B}$ is direct solar radiation on horizontal surface, and $I_{d}$ - diffuse solar radiation on horizontal surface.

\section{EXPERIMENT}

At implementation of solar power for the production of energy, it is necessary to measure the solar radiation as a necessity for the design and introduction of solar panels to choose positions in space where their effectiveness will be maximized.

The installation used at measuring of solar energy radiation has presented before in Fig.1, and a schematic diagram is shown in Fig.3. It can be observed that for measuring the total and diffuse solar radiation intensity were used a photovoltaic sensor type LS 200 from KIMO Instruments, whose properties are shown in Tab.1 [24]. Solar radiation data, converted as an electrically analog signal, are transmitted to a data acquisition system (ADS), which, after the conversion into a digital format, will send the information to a data processing unit, in order to build a database (DB). Data processing units have characterized by an important development in last years, in terms of both hardware and software. Today on the technological market, there are equipments with data processing units or only with memory environments, which will be recorded in a PC for a processing process, developed by a specialist in a virtual tool [4-8, 14-19, 23].

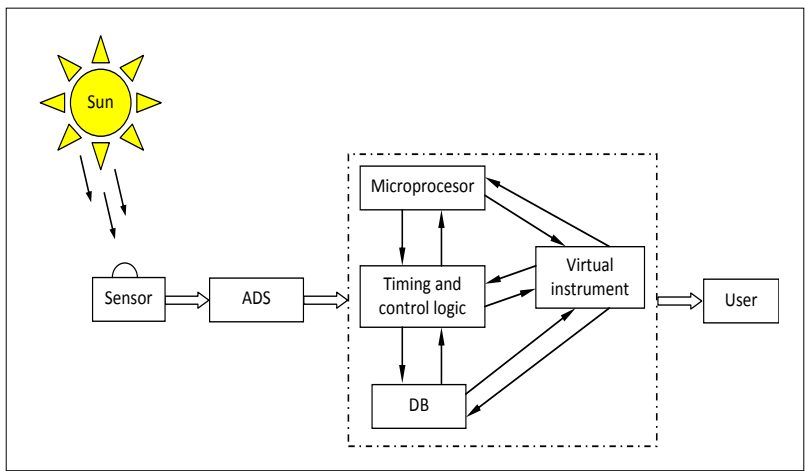

Fig. 3. System for measuring solar radiation

\begin{tabular}{|l|l|}
\hline \multicolumn{1}{|c|}{ Parameters } & \multicolumn{1}{c|}{ Value/Type } \\
\hline Spectral response & $400 \mathrm{~nm}$ to $1100 \mathrm{~nm}$ \\
\hline Nominal calibration coefficient & $100 \mathrm{mv}$ for $1000 \mathrm{~W} / \mathrm{m}^{2}$ \\
\hline Coefficient in temperature & $+0.1 \% /{ }^{\circ} \mathrm{C}$ \\
\hline Operating temperature & $-30{ }^{\circ} \mathrm{C}$ to $+60^{\circ} \mathrm{C}$ \\
\hline Humidity dependence & $100 \% \mathrm{HR}$ \\
\hline Mode & Photovoltaic \\
\hline Surface active & $1 \mathrm{~cm}^{2}$ \\
\hline Material & Polycrystalline silicon \\
\hline Cell weight & $60 \mathrm{~g}$ \\
\hline Cell dimensions & $39 \times 32 \mathrm{~mm}$ \\
\hline
\end{tabular}

Tab. 1. Properties of the solar radiation sensor type LS 200 [24]

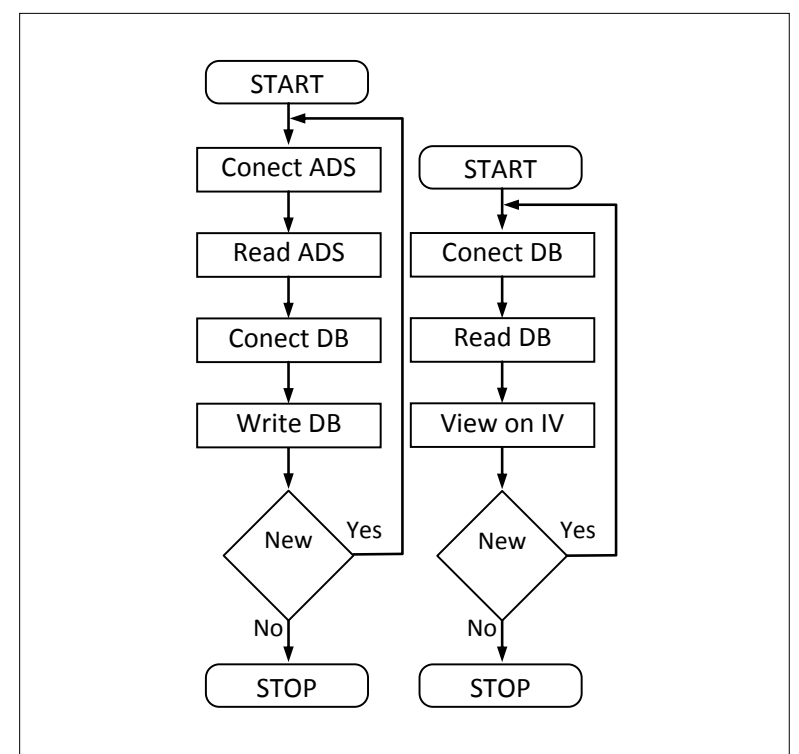

Fig. 4. Organizational read/write database

The data visualization and analysis by the user can be developed by a virtual tool, which was created by the authors using LabVIEW program. This graphical programming environment was revolutionized application development testing, measurement and control. Through this program, regardless of experience, engineers and scientists can rapidly and effectively interface with the acquisition and control hardware, analyze data and can design distributed systems. The graphical programming environment offered by LabVIEW virtual instrument defines a software module (program), which consists of a user's interface front panel (which provides an intuitive picture of a classical instrument) and a type-scheme program block (a chart, available for repairs and maintenance).

In database terms, these items can be created and automatically updated or on request of the user. For each measurement will be generated a unique identification and registration which will contain measured solar radiation, the sensor position in space, time and date when the measurement was developed. Organizational insertion/extraction of data and the database are shown in Fig. 4, which was used to experiments.

\section{RESULTS AND DISCUSSIONS}

The program performs two measurements per second and records in the database the average result for 60 seconds. Data on the solar radiation obtained after the measurements are stored for every minute, over 24 hours (one day). Data are given as graphs or numerically.

During of 24 hours it was measured the intensity of solar radiation and the radiant exposure or global irradiance, used the installation from Fig.1. The data obtained can determine the maximum amount of solar radiation intensity and the average values for a day light (east - sunset) or for 24 hours. Furthermore, the instruments allow determination of energetic exposure of global irradiance $\left[\mathrm{Wh} / \mathrm{m}^{2}\right]$. Depending on the results obtained, it can be designed the solar energy conversion equipment required. The sensor is placed horizontally in areas of freedom degrees of the horizon $360^{\circ}$. 


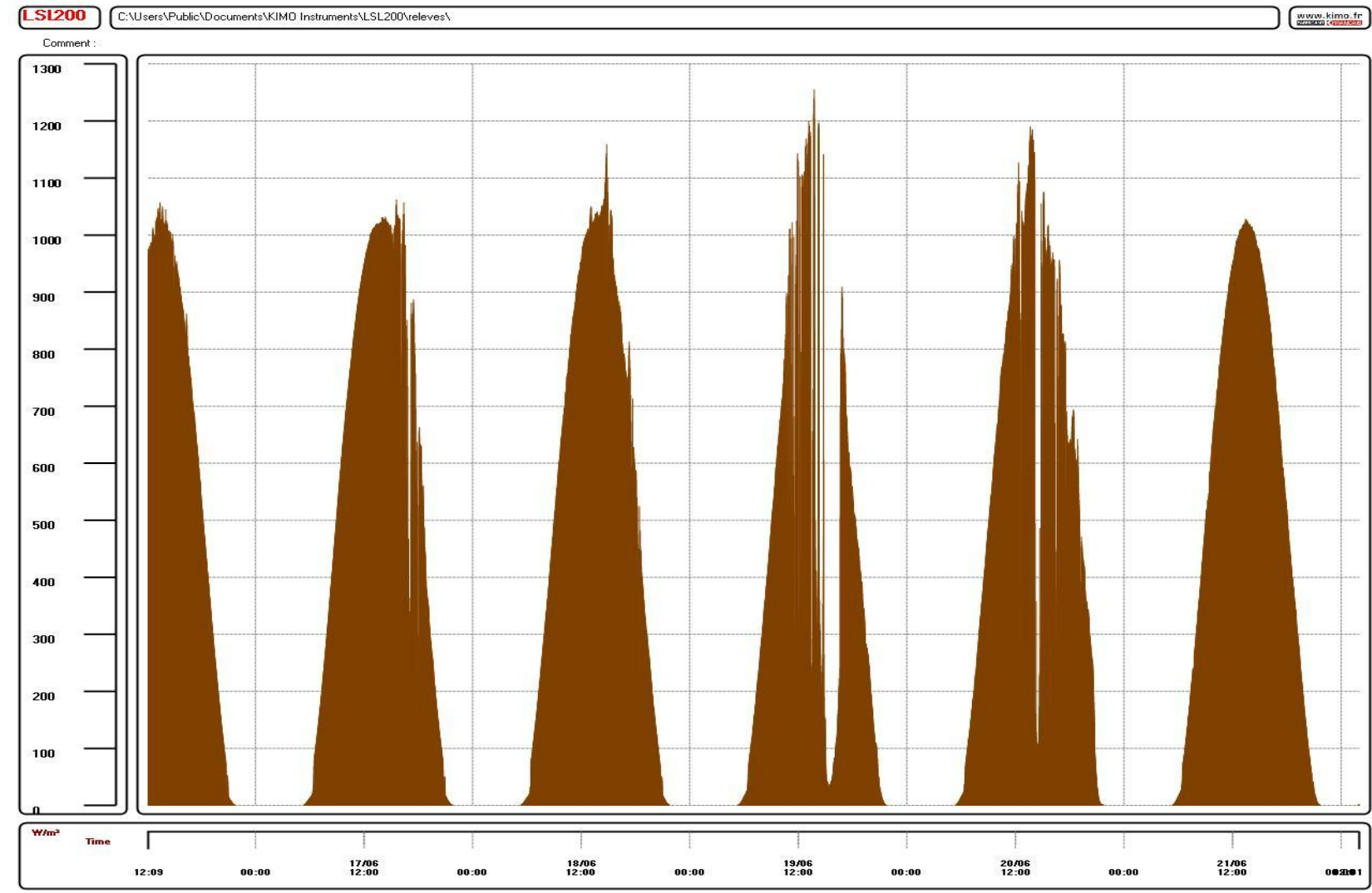

Fig. 5. Measurements during of June 16 to 22 in Stâna de Vale

The measurements have taken place at the Gaudeamus Didactic Base of Oradea University from Stana de Vale (Stana de Vale is a winter Spa in Apuseni/Carpati mountains, at approx. $90 \mathrm{~km} \mathrm{S-SE} \mathrm{of}$ Oradea), and in the campus of University of Oradea. The measurements began on April $11^{\text {th }} 2012$ and ended on June $27^{\text {th }} 2012$.
One sample of these tests and recorded/plotted with LS 200 solarimeter is presented in Fig. 4, which represent the results of measurements during of 16 to 22 of June 2012 in Stana de Vale. Similar, in Fig.5, we are presented the measurements' results during of 13 to 27 of June 2012 in Oradea.

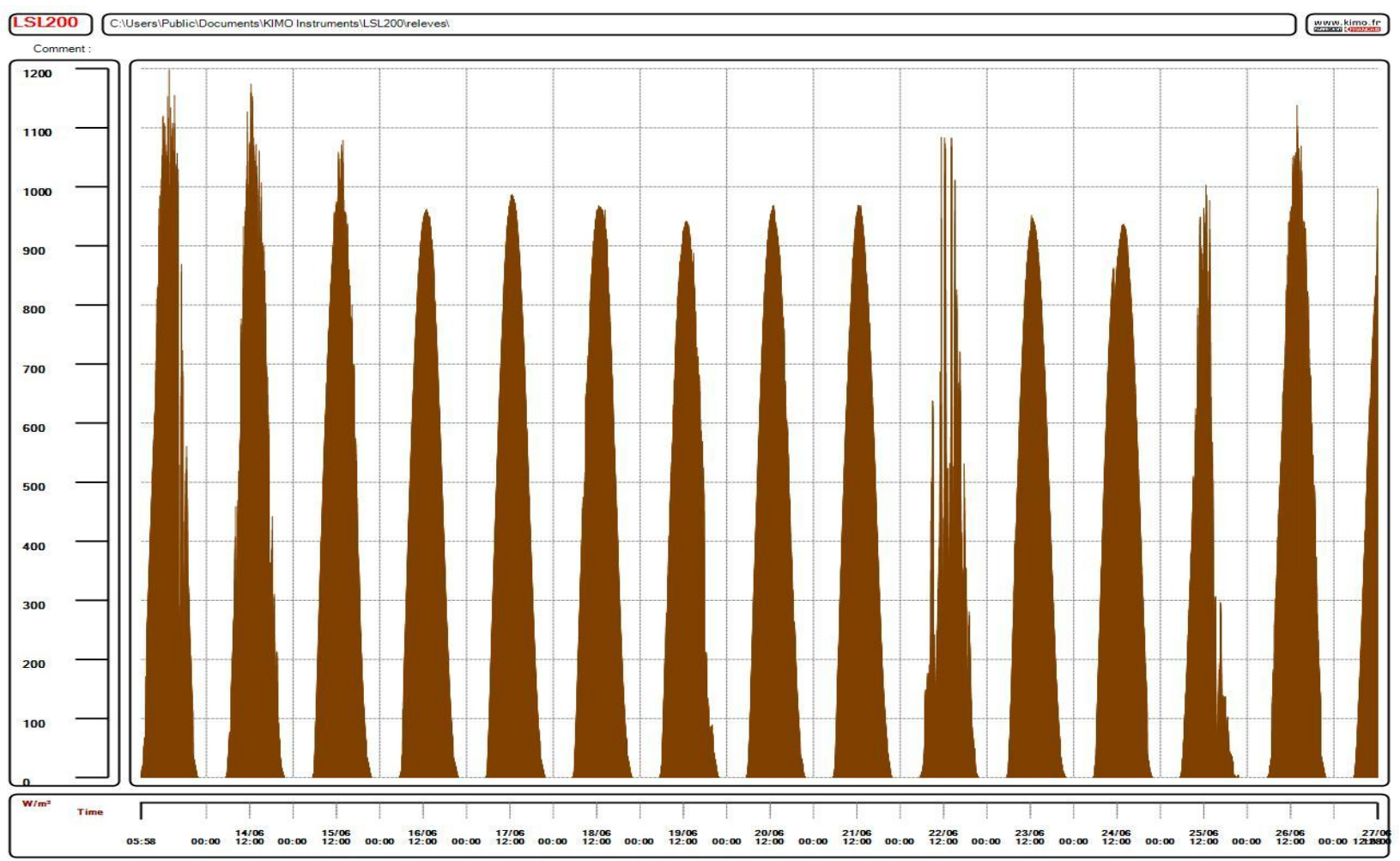

Fig. 6. Measurements during of June 13 to 27 in Oradea 


\begin{tabular}{|l|c|c|c|}
\hline $\begin{array}{c}\text { Date of } \\
\text { Measurments }\end{array}$ & $\begin{array}{c}\text { Maxim } \\
\text { irradiance } \\
{\left[\mathbf{W} / \mathbf{m}^{2}\right]}\end{array}$ & $\begin{array}{c}\text { Average } \\
\text { irradiance } \\
{\left[\mathbf{W} / \mathbf{m}^{2}\right]}\end{array}$ & $\begin{array}{c}\text { Global } \\
\text { irradiance } \\
{\left[\mathbf{W h} / \mathbf{m}^{2}\right]}\end{array}$ \\
\hline $11-21.04 .12$ & 1206 & 97 & 22304 \\
\hline $21-29.04 .12$ & 1234 & 220 & 44358 \\
\hline $29.04-02.05 .12$ & 1131 & 288 & 21345 \\
\hline $08-16.05 .12$ & 1254 & 157 & 30111 \\
\hline $16.05-02.06 .12$ & 1301 & 167 & 66932 \\
\hline $02-16.06 .12$ & 1280 & 208 & 70281 \\
\hline $16-22.06 .12$ & 1255 & 361 & 44382 \\
\hline & \multicolumn{5}{|l}{} \\
\hline Mean & 1234.33 & 189.50 & 42555.16 \\
\hline SD & 60.65 & 64,95 & 21822.19 \\
\hline SE & 24.76 & 26.51 & 8908.87 \\
\hline
\end{tabular}

Tab. 2.Results of data measurements in Stana de Vale

SD-standard deviation; SE-standard error means

The details of experiments about the data of solar irradiance results (maxim, average and global irradiance) are presented in Tab.2 and Tab.3. Also, the variations of global solar irradiance's tests made in Stana de Vale are presented in Fig.6, and for Oradea in Fig.7, respectively.

Furthermore, for a better assessing of data measurements, these results were been analyzed and processed in both cases by using the SPSS Statistic Program v.19.

At a first analyzing of the results, we can be observed that in both cases the maximum value of solar irradiance was almost the same, $1301 \mathrm{~W} / \mathrm{m}^{2}$ in Stana de Vale at time of 15.05-02.06.2012, respectively $1300 \mathrm{~W} / \mathrm{m}^{2}$ in Oradea at time of 31.05-13.06.2012. The differences were been more evident to statistic calculus of means values such as $1234.33 \pm 66 \mathrm{~W} / \mathrm{m}^{2}$ at Stana de Vale vs. $1174.40 \pm 128 \mathrm{~W} / \mathrm{m}^{2}$ at Oradea. More than, analyzing these times of measurements, we can be seen that the average value for Stana de Vale was $167 \mathrm{~W} / \mathrm{m}^{2}$ that is smaller as for Oradea as $220 \mathrm{~W} / \mathrm{m}^{2}$, due to the influences of different weather conditions and geographical locations.

\begin{tabular}{|l|c|c|c|}
\hline $\begin{array}{c}\text { Date of } \\
\text { Measurments }\end{array}$ & $\begin{array}{c}\text { Maxim } \\
\text { irradiance } \\
{\left[\mathbf{W} / \mathbf{m}^{2}\right]}\end{array}$ & $\begin{array}{c}\text { Average } \\
\text { irradiance } \\
{\left[\mathbf{W} / \mathbf{m}^{2}\right]}\end{array}$ & $\begin{array}{c}\text { Global } \\
\text { irradiation } \\
{\left[\mathbf{W h} / \mathbf{m}^{2}\right]}\end{array}$ \\
\hline $18-29.04 .12$ & 1243 & 243 & 66533 \\
\hline $29.04-03.05 .12$ & 989 & 286 & 25311 \\
\hline $08-18.05 .12$ & 1096 & 191 & 48656 \\
\hline $18-31.05 .12$ & 1244 & 272 & 84915 \\
\hline $31.05-13.06 .12$ & 1300 & 220 & 65342 \\
\hline $13-27.06 .12$ & 1198 & 315 & 107762 \\
\hline \multicolumn{4}{|l}{} \\
\hline Mean & 1174.40 & 242.40 & 58141.40 \\
\hline SD & 128.30 & 38.74 & 22399.22 \\
\hline SE & 57.37 & 17.20 & 10017.23 \\
\hline
\end{tabular}

Tab. 3. Results of data measurements in Oradea

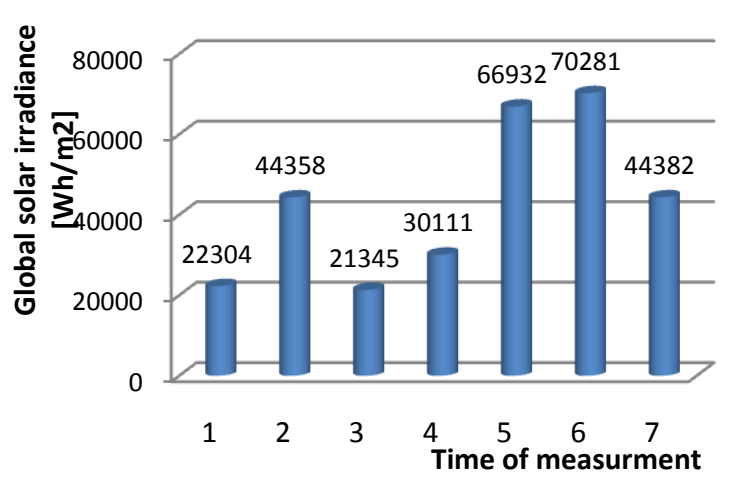

Fig. 7. Variations of global solar irradiance for tests in Stana de Vale

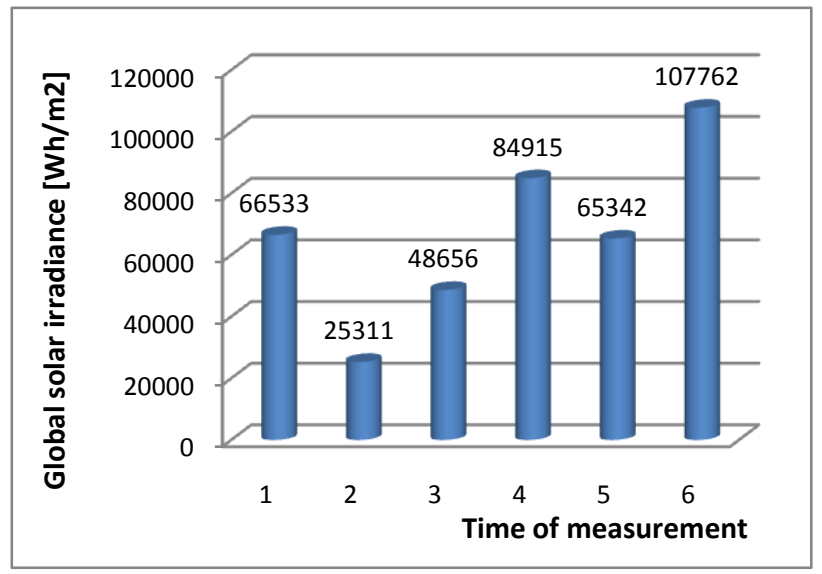

Fig. 8. Variatiosn of global solar irradiance for tests in Oradea

In both tests, the values of global irradiance are reasonable with a maxim of $107762 \mathrm{Wh} / \mathrm{m}^{2}$ in Oradea and $70281 \mathrm{Wh} / \mathrm{m}^{2}$ in Stana de Vale, respectively. The proportion was kept and for statistic calculus of means values. The global irradiance is an important parameter that shows the intensity of solar power per hour and meter squares, and represents a significant factor in optimal selection of thermal or photovoltaic features.

These good results of tests underline the performance of dynamic installation and its original program used for evaluation of solar irradiance that open the future implementation of solar power energy in University of Oradea in both locations. For that, we were selected the solar panels type CS5A-175M from Canada (Tab.4), which is a robust solar module with 75 solar cells.

Next researches will be focused on continuing of solar radiation measuring using this installation to find future possible implementations of solar power energy in other zones from Oradea City and Bihor County to develop the green energy in $\mathrm{N}-\mathrm{V}$ of Romania.

\begin{tabular}{|l|l|}
\hline \multicolumn{1}{|c|}{ Parameters } & \multicolumn{1}{c|}{ Value/Type } \\
\hline Nominal Maximum Power (Pmax) & $175 \mathrm{~W}$ \\
\hline Optimum Operating Voltage (Vmp) & $35.8 \mathrm{~V}$ \\
\hline Optimum Operating Current (Imp) & $4.89 \mathrm{~A}$ \\
\hline Module Efficiency & $13.71 \%$ \\
\hline Operating Temperature & $-40{ }^{\circ} \mathrm{C}+85^{\circ} \mathrm{C}$ \\
\hline Maximum System Voltage & $1000 \mathrm{~V}$ (IEC) /600V (UL) \\
\hline Application Classification & Class A \\
\hline Cell Type & Mono-crystalline $125 \mathrm{x}$ \\
& $125 \mathrm{~mm}, 2$ Busbars \\
\hline Dimensions & $1580 \times 808 \times 40 \mathrm{~mm}$ \\
\hline Weight & $15.8 \mathrm{~kg}$ \\
\hline
\end{tabular}

Tab. 4. Properties of the solar panels type CS5A-175M [25] 


\section{CONCLUSIONS}

This paper has presented a method for investigation of solar power irradiance measured in a particular geographic area of Bihor County from Romania.

The experiments have performed by an installation with LS 200 that allowed determination of solar irradiance (maximum, average and global irradiance). The tests were been made over a period of four months, and the installation program facilitated registration and interpretation of data for every minute and over 24 hours. The results were performed both diagrams and numerical data using original programs with LabVIEW. The size of results was direct influenced of different weather conditions and geographical locations.

This installation offered important information about the evaluation of the produced electric powers, optimum orientation of solar panels and performance's follow-up, choice the photovoltaic generators features.

The good results of experiments allow the future implementation of solar panel's type CS5A-175M in University of Oradea and in Stana de Vale at Gaudeamus University Base, which due to significantly economy for our university on long time and energetically autonomy.

The researches of solar radiation will be going on to improve the measuring installation and to find the possible next generalization of solar energy power in our town and Bihor County.

\section{ACKNOWLEDGEMENTS}

The authors would like to thank Trans-frontally EU Grant "HURO/0802/083 AF" [Acronym-REGENERG], with the title "Contributions at the efficient usage of regenerable energies from Bihor County and HajduBihar County" for the financial support.

\section{REFERENCES}

[1] Chu, S.X. \& Liu, L.H. (2009), Analysis of terrestrial solar radiation energy, Solar Energy, Vol. 83, Issue 8, pp. 1390-1404

[2] Gibson, G.H. (2000), UVB Radiation. Definition and characteristics, USDA UVB Monitoring Program Natural Resource Ecology Laboratory Colorado State University, USA, $u v b \_$primer.pdf, pp.1-10

[3] Golden, G. (2011), Renewables - disruptors or disrupted? The contribution of wind, solar, and bioenergy systems may be determined by the cost of materials and of natural gas, Mechanical Engineering Mag. of ASME, Vol. 133/12, pp.30-34

[4] Gordan, C. \& Reiz, R. (2008), The analysis and signals synthesis, University of Oradea Ed., ISBN 978-973-759-642-0, Oradea

[5] Gordan, C. \& Reiz, R. (2006), Filters, University of Oradea Ed., ISBN 978-973-759-176-0, Oradea, Romania

[6] Gordan, I. M., Gordan, C. \& Pop, A.P. (2009), Enhance of house control by using LabView, Annals of DAAAM for 2009, Proceedings of the 20th International DAAAM Symposium, Vienna, Austria, 25-28 Nov. 2009, ISBN 978-3-901509-70-4, ISSN 1726-9679, Katalinic, B. Ed. pp.1341-1342, DAAAM International Vienna Publisher, Vienna

[7] Gordan, I.M., Pop A.P. \& Gordan C. (2009), The modeling of small power bridge by Simulink program, Annals of DAAAM for 2009 \& Proceedings of the 20th International DAAAM Symposium, Vienna, Austria, 25-28 Nov. 2009, ISBN 978-3901509-70-4, ISSN 1726-9679, Katalinic, B. Ed. pp.1305-1306, DAAAM International Vienna Publisher, Vienna
[8] Gordan, I.M. (2003), Electrical measurements in electrical engineering, University of Oradea Ed. ISBN 973-613-260-9, Oradea

[9] Lopez, G., Batlles, F.J. \& Tovar-Pescador, J, (2005), Selection of input parameters to model direct solar irradiance by using artificial neural networks, Energy, Vol. 30/2005, Elsevier Ed, pp.1675-1684

[10] Novac M., Novac O., Gordan M. \& Gordan C. (2011), Numerical modeling of electromagnetic induction heating process using an inductor with constant step between turns, International Conference on Industrial Electronics, Technology \& Automation, (IETA 11)-CISSE 2011, University of Bridgeport, USA, 3-12 December 2011, Book: Innovations and Advances in Computer Information Systems Sciences and Engineering, Series: Lecture Notes in Electrical Engineering, Vol. 152/2012, CISSE's Publisher Springer

[11] Oprea, C. (2005), Solar radiation. Theoretical and practical aspects, Technical Ed., ISBN 973-03915-1, Bucharest

[12] Pop, P.A. (2010), "MEMS- Introductive elements", University of Oradea Ed., ISBN 978-606-10-0249-8, Oradea

[13] Pop, P.A., Veres, M., Iancu, C., Mihaila, S. \& Ungur, P. (2008), Heating installation of sewage water with solar captor, Annals of DAAAM for 2008 \& Proceedings of the 19th International DAAAM Symposium, 22-25th October 2008 Trnava, Slovakia, ISBN 978-3-901509-70-4, ISSN 1726-9679, Katalinic, B. Ed, pp.1099-1100, DAAAM International Vienna Publisher, Vienna

[14] Purcaru, D., Gordan, C. \& Purcaru, A. (2011), Application of the I-7000 Rempte controllable data acquisition modules in a measurement system with inductive sensors, Journal of Electrical and Electronics Engineering, University of Oradea Publisher, Vol.4, No.1/2011, pp. 203-206, ISSN 1844 -6035

[15] Purcaru, D., Gordan, C., Purcaru, A. \& Reiz, R. (2010), Robust and low cost PC104 interface with synchronized sampling of analog inputs: hardware solution, International Conference on Mechanical Engineer, Robotics and Aerospace ICMERA2010, 24 Dec. 2010 Bucharest, IEEE Catalog No. CFP1057L-ART ISBN 978-1-4244-8868-1, IEEE Catalog Number CFP1057LPRT ISBN 978-1-4244-8867-4, pp. 250-254

[16] Purcaru, D., Purcaru, A., Gordan, C. \& Niculescu, M. (2010), Digital Equipment for the Implementation of Complex Protection Functions, Journal of Electrical and Electronics Engineering, , Vol.3, No.1/2010, pp. 171-174, University of Oradea Publisher, Oradea, ISSN 1844 -6035

[17] Purcaru, D., Purcaru, A., Gordan, C., Niculescu, M., Proca, V. \& Vintila, A. (2009), Bending stress measurement system and procedure for experimental training of undergraduates on electronics and measurement techniques, WSEAS Transactions on Advances in Engineering Education, , Issue 5, Vol.6, May 2009, pp.131-141, ISSN 1790-1970

[18] Purcaru, D., Gordan, C., Purcaru, I. \& Niculescu, M. (2009), Intelligent measurement system with strain gauge sensor for engineering education, Proceedings of the 5th WSEAS/IASME International Conference on Educational Technologies EDUTE' 09, pp. 75-80, ISSN 1790-5109, ISBN 978-960-474-092-5

[19] Purcaru, D.M., Purcaru, I., Gordan, C., Niculescu, E. \& Nedelcut, S.D. (2008), Application of Fourier method in energetics, for root-mean-square value and phase shift measurement, IEEE International Conference on Automation, Quality and Testing, Robotics AQTR 2008, 22-25 May2008 Cluj Napoca, Romania, THETA 16TH Edition, Vol. III, Proceedings, pp. 187-192

[20] Radosavljevic, J. \& Dordevic, A. (2001), Defining of the intensity of solar radiation on horizontal and oblique surfaces on earth, Facta Universitatis, Series: Working and Living Environmental Protection Vol. 2, No 1, pp. 77 - 86

[21] Vijayakumar, G., Kummert, M., Klein, S.A. \& Beckman, W.A. (2005), Analysis of short-term solar radiation data, Solar Energy, Vol. 79, Issue 5, pp. 495-504

[22] Vancea, C., Gordan, I.M. \&. Popa, T.M. (2009), Constructive and functional upgrading opportunities for the heat section from University of Oradea, Nonconventional Technologies Review, No. 3/2009, pp. 93-97, Bucharest

[23] *** (2011), LabVIEW of course manual

[24] *** (2010), LS 200 Solarimeter's handbook, KIMO Instruments.

[25] *** (2011), Technical data of CSA5 solar panels, Solar Canadian Inc 